\title{
ISOLATION AND MOLECULAR IDENTIFICATION OF POTENTIALLY PATHOGENIC Escherichia coli AND Campylobacter jejuni IN FERAL PIGEONS FROM AN URBAN AREA IN THE CITY OF LIMA, PERU
}

\author{
Moisés CABALLERO(1), Isabel RIVERA(1), Luis M. JARA(1), Francisco M. ULLOA-STANOJLOVIC(2) \& Carlos SHIVA(1)
}

\begin{abstract}
SUMMARY
Feral pigeons (Columbia livia) live in close contact with humans and other animals. They can transmit potentially pathogenic and zoonotic agents. The objective of this study was to isolate and detect strains of diarrheagenic Escherichia coli and Campylobacter jejuni of urban feral pigeons from an area of Lima, Peru. Fresh dropping samples from urban parks were collected for microbiological isolation of E. coli strains in selective agar, and Campylobacter by filtration method. Molecular identification of diarrheagenic pathotypes of E.coli and Campylobacter jejuni was performed by PCR. Twenty-two parks were sampled and 16 colonies of Campylobacter spp. were isolated. The $100 \%$ of isolates were identified as Campylobacter jejuni. Furthermore, 102 colonies of E. coli were isolated and the $5.88 \%$ resulted as Enteropathogenic (EPEC) type and $0.98 \%$ as Shiga toxin-producing E. coli (STEC). The urban feral pigeons of Lima in Peru can act as a reservoir or carriers of zoonotic potentially pathogenic enteric agents.
\end{abstract}

KEYWORDS: Escherichia coli; Campylobacter jejuni; Diarrhea; Zoonoses; PCR.

\section{INTRODUCTION}

The feral pigeons (Columbia livia) live in urban and rural areas, in close contact with humans and other animals. In recent years, the population growth of feral pigeons has increased their interest in public health, because it could represent a reservoir of transmissible pathogens by air and through contaminated food or water ${ }^{29}$.

Among the zoonoses that could be transmitted by pigeons, the most important are chlamydiosis, cryptococcosis, aspergillosis and enterobacteriosis, which include pathogenic Escherichia coli and species of Campylobacter, Salmonella and Listeria ${ }^{1}$. Five main pathotypes of diarrheagenic E. coli have been described, enterotoxigenic (ETEC), enteropathogenic (EPEC), enteroaggregative (EAEC), enteroinvasive (EIEC) and the zoonotic enterohemorrhagic (EHEC or STEC), which produce a Shiga-like toxin that leads to hemolytic uremic syndrome ${ }^{33}$. Some studies show that enterohemorrhagic serotype O157:H7 of E. coli can be present in feral pigeons ${ }^{15,28}$. Moreover, in Peru there have been reported outbreaks of human enterohaemorrhagic colibacilosis from unknown sources of infection ${ }^{13}$, although prevalence of STEC in children is up to $9 \%$ while EPEC is higher ${ }^{21}$.

Thermotolerant Campylobacter species have become important, especially as agents of infectious diarrhea, with even more cases per year than salmonellosis and shigellosis ${ }^{11,33}$. Campylobacter jejuni and Campylobacter coli are the most frequent cause of diarrhea in childhood groups, the fecal-oral route being the main route of transmission ${ }^{3,6}$. Even more, Campylobacter has been isolated from river and waste water, chickens and pets ${ }^{32}$. In Lima, C. jejuni was reported as responsible for the $13.3 \%$ of the acute human diarrhea diagnosed in local hospital centers $^{25}$.

There are no studies about the prevalence of zoonotic diarrheagenic agents in urban birds in the city of Lima, Peru. Their population has increased in recent years and the close contact with people in public places, especially with children, requires knowledge of the epidemiological status of potential pathogenic E. coli and Campylobacter in feral pigeons. Given this context, the objective of this study was to isolate and identify the presence of Campylobacter jejuni and diarrheagenic E. coli in feral pigeons from an urban area in the city of Lima, Peru, through the microbiological isolation and molecular identification by a conventional Polymerase Chain Reaction (PCR) technique.

\section{MATERIALS AND METHODS}

Sampling: droppings samples, from healthy adult feral pigeons, were collected in parks (22) of a midwest area of the city of Lima (Pueblo Libre), Peru, in the summer (December to April) of 2012. Sterile plastics with food were extended on the ground of each park, and a swab of fresh droppings from each pigeon (about 30 animals per park) was obtained. Swabs were placed in a Stuart transport medium and then were stored at $4{ }^{\circ} \mathrm{C}$ for 24 hours.

(1) Universidad Peruana Cayetano Heredia, Facultad de Veterinaria y Zootecnia, Lima, Perú.

(2) Universidade de São Paulo, Faculdade de Veterinária e Zootecnia, São Paulo, SP, Brasil.

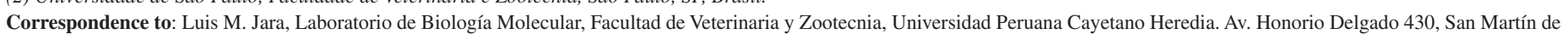
Porres, Lima, Perú. E-mail: luis.jara.s@upch.pe 


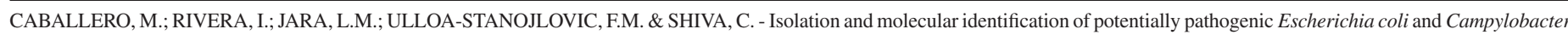
jejuni in feral pigeons from an urban area in the city of Lima, Peru. Rev. Inst. Med. Trop. Sao Paulo, 57(5): 393-6, 2015.

Microbiological and molecular identification: samples for $E$. coli isolation were seeded and cultured in MacConkey agar by the streaking culture technique and incubated at $37{ }^{\circ} \mathrm{C}$ for 24 hours in aerobiosis. Samples for Campylobacter were suspended in $1 \mathrm{~mL}$ of saline solution and inoculated into a cellulose filter $(0.45 \mu \mathrm{m})$ on blood agar and then incubated for 72 hours at $42{ }^{\circ} \mathrm{C}$ under microaerophilic conditions $^{22}$. According to biochemical patterns and modified Gram staining with fuchsin, E. coli and Campylobacter were presumptive identified respectively ${ }^{34}$. The extraction of genomic DNA of each colony was performed by the kit Wizard Genomic DNA Purification for Gramnegative bacteria, according to the supplier's instructions (Promega, USA).

For the molecular identification of diarrheagenic E. coli pathotypes, a multiplex PCR performed with previously described primers of intimin (eae), Shiga toxin (stx1, stx2) and hemolysin (hlyA) was used $^{23}$. As well for the $C$. jejuni identification, the previously described primers forward 5'- TGACGCTAGTGTTGTAGGAG - 3' and reverse 5' -CCATCATCGCTAAGTGCAAC-3' were used in a conventional $\mathrm{PCR}^{20}$. Diarrheagenic $E$. coli pathotypes were classified according to the presence of virulence factors eae for EPEC and stx $1 /$ stx 2 for $\mathrm{STEC}^{21}$. The prevalence was expressed as a percentage according to the pathotype found in the total of isolates.

\section{RESULTS}

From all samples seeded on blood agar, 16 colonies were isolated showing microscopic characteristics such as small size, pinpoint morphology, non-hemolytic, and Gram-negative "gull-wing" shaped bacilli at Gram staining. One hundred percent of colonies suggestive of

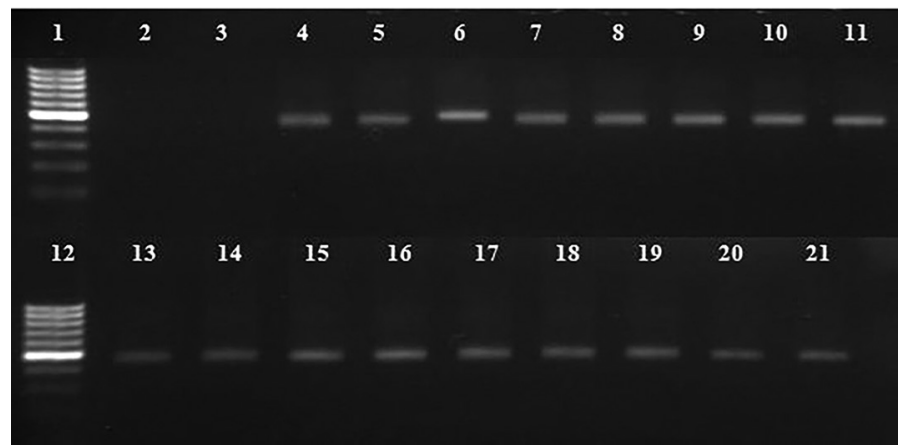

Fig. 1 - Gel electrophoresis of C. jejuni samples from feral pigeons. Ladder 100 bp (1); blank (2), negative control, E. coli ATCC 25922 (3); positive control, C. jejuni No. 1503-2012 (4); positive colonies (5-21). PCR product: $402 \mathrm{bp}^{16}$
Campylobacter were positive in PCR identification as C. jejuni (Fig. 1). Likewise, 110 colonies of $E$. coli were isolated from McConkey agar, of which only 102 were confirmed by biochemical tests. The $6.86 \%$ of the E. coli strains amplified had one or more virulent genes, of which $5.88 \%$ belonged to the EPEC group and $0.98 \%$ to the STEC group (Table 1, Fig. 2).

\section{DISCUSSION}

This study represents the first report of potentially pathogenic agents isolated from urban feral pigeons in Lima, Peru. The results indicate that these birds, settled in different parks, can serve as a reservoir of zoonotic C. jejuni and STEC, as well as EPEC. Although the isolation and molecular identification methodology was similar to previous studies, and there were no differences among parks tested, the prevalence obtained may differ by the number of samples collected and sampling areas, among other investigated factors.

The presence of Campylobacter jejuni has been documented worldwide in urban birds. In Spain this was found, with $69.1 \%$ in contrast to $1.1 \%$ of $C$. coli $^{32}$. Also in Sweden, a study found $3 \%$ of prevalence of . $_{\text {jejuni }}{ }^{19}$, while in Chile a $7 \%$ was found ${ }^{10}$. In Bolivia a $29 \%$ of frequency for Campylobacter spp. was obtained and $57 \%$ was confirmed as $C$. jejuni ${ }^{2}$. And in the Peruvian jungle, $C$. jejuni was found in $8 \%$ of the domestic chickens sampled ${ }^{31}$.

The role of Campylobacter in the etiology of human enteric disease has been established in developing countries, and there is a consensus that the environment and level of sanitary care are crucial in infections ${ }^{11}$. In USA, the $15 \%$ of Campylobacter infections have been due to contact with pets ${ }^{18}$, with a wide range of reservoirs among mammals and birds present in the surroundings. As reported, $C$. jejuni isolates from clinically

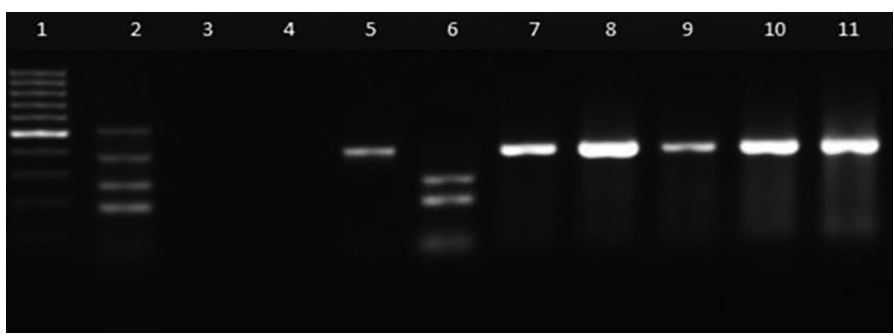

Fig. 2 - Gel electrophoresis of diarrheagenic E. coli samples from feral pigeons. Ladder 100 bp (1); positive control E. coli O157:H7 (2), negative control E. coli ATCC 25922 (3); blank (4), positive colonies EPEC (5,7-11); positive colony STEC (6). PCR products: 180 bp (stx1), $255 \mathrm{bp}$ (stx2), $384 \mathrm{bp}($ eae $)$ and $534 \mathrm{bp}(\text { hylA })^{15}$

Table 1

Classification of pathogenic E. coli isolates

\begin{tabular}{|c|c|c|c|c|c|}
\hline \multicolumn{4}{|c|}{ Virulence factors ${ }^{a}$} & \multirow{2}{*}{ Pathotype of E. coli } & \multirow{2}{*}{ No. of colonies ${ }^{b}$} \\
\hline eae & stxl & stx 2 & hylA & & \\
\hline+ & - & - & - & EPEC & $6(5.88 \%)$ \\
\hline \multirow[t]{2}{*}{-} & + & + & - & STEC & $1(0.98 \%)$ \\
\hline & & & & Total & $7(6.86 \%)$ \\
\hline
\end{tabular}

\footnotetext{
${ }^{\mathrm{a}}+$ presence of gene; - absence of gene; ${ }^{\mathrm{b}}$ From a total of 102 E. coli isolates.
} 


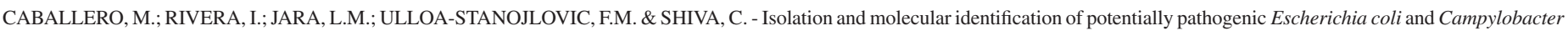
jejuni in feral pigeons from an urban area in the city of Lima, Peru. Rev. Inst. Med. Trop. Sao Paulo, 57(5): 393-6, 2015.

healthy homing pigeons can invade human enterocytes in vitro ${ }^{30}$. In some prevalence studies about human diarrhea in Peru, Campylobacter has been isolated more frequently from children. In the north of Lima, a study showed that $10 \%$ of patients with diarrhea were carriers of the bacteria, $C$. coli (5\%), followed by C. jejuni $(2.9 \%)$ and C. lari $(2.1 \%)$ being the most frequently observed among children under the age of $5^{5}$. Furthermore, in clinical samples from some hospitals in Lima, 37 positive cases for Campylobacter spp. were obtained from children under one year-old ${ }^{14}$. However, a previous study indicated that exposure to the domestic poultry feces was the predominant risk factor for diarrhea in children ${ }^{12}$.

The presence of pathogenic E. coli in urban feral pigeons has been reported mainly in developed countries as USA where $7.9 \%$ of the isolates corresponded to the STEC group ${ }^{24}$; whereas in the present study less than $1 \%$ was obtained. Other studies in Brazil showed that EPEC and ETEC were present in around $12.1 \%$ of feral pigeon droppings ${ }^{29}$. In Finland, the EPEC group presented a prevalence of $7 \%{ }^{16}$, similar to the results of the present study where EPEC represented $5.88 \%$ of the total isolations. Recently, in Spain they reported the EPEC group (6\%) from urban pigeons, but no STEC was found, in contrast with our study where STEC was isolated ${ }^{27}$. According to a study in Lima, where 113 isolates of $E$. coli were collected from human diarrheic feces, $13.3 \%$ carried the eae gene (EPEC group); in addition, strains of ETEC, STEC, EAEC and EIEC $^{21}$ were found. Conversely, the implication of EPEC and STEC groups in neonatal diarrhea has been demonstrated in livestock, STEC being of zoonotic importance. In addition, it has been suggested that saprophytic $E$. coli strains, in exchanging genetic material from different sources, could become pathogenic if they acquire genetic sequences for specific virulence factors ${ }^{17}$. Thus, it is suggested that intestinal isolates from healthy birds could cause disease in susceptible hosts, depending on the combination of the virulence factors that occur ${ }^{4}$.

It is known that direct and indirect contact with animals and food products may be of importance in the transmission of human STEC infections, especially of serotype $\mathrm{O} 157: \mathrm{H} 7$, which has been isolated from chickens and wild birds ${ }^{7,9}$. However, this study could not demonstrate the presence of E. coli STEC with more virulence genes than eae or hylA, which would have suggested a zoonotic enterohemorrhagic serotype. On the other hand, contamination of the environment is an important factor to consider with respect to the exposition to STEC in farm animals, which would keep the epidemiological cycle of pathogenic strains ${ }^{26}$. It is also known that the water that is used to irrigate many urban parks does not receive an adequate treatment, if they receive it at all, and serves as drinking water for animals, which could sustain the persistence of many enteropathogens in urban birds and its presence on human diarrhea, as has been suggested in a epidemiological study in a collective community in Israel $^{8}$.

The results of this study show, for the first time, the epidemiological status of diarrheagenic and zoonotic bacteria in urban feral pigeons of Lima, Peru. Further studies exploring previous exposure to birds or animal feces, antibiotic resistance profile in birds strains, and genotyping and phylogeny analysis between strains of human and animal source may contribute to fulfill the lack of epidemiological data in the country, and alert the national health authorities for the need of establishing preventive and control measures in order to reduce the possible causes of potential zoonoses.

\section{RESUMO}

\section{Isolamento e detecção de Escherichia coli e Campylobacter jejuni potencialmente patogênicos em pombos selvagens de uma área urbana na cidade de Lima, Perú}

Os pombos selvagens (Columbia livia) vivem em estreito contato com os seres humanos e outros animais. Podem transmitir agentes potencialmente patogênicos e zoonóticos. Os objetivos deste estudo foram isolar e detectar cepas de Escherichia coli diarreiogênica e Campylobacter jejuni de pombos selvagens urbanos de uma área de Lima, Peru. Amostras de fezes frescas foram coletadas em parques urbanos para o isolamento microbiológico para cepas de E. coli em ágar seletivo e Campylobacter por método de filtração. Identificação molecular de patótipos diarreiogênicos de E. coli e Campylobacter jejuni foi realizado por PCR. Vinte e dois parques foram amostrados e 16 colônias de Campylobacter spp. foram isolados. O 100\% dos isolados foram identificados como Campylobacter jejuni. Além disso, 102 colônias de E. coli foram isoladas e 5,88\% resultaram como tipo enteropatogênico (EPEC) e 0,98\% como produtora de toxina Shiga (STEC). Os pombos selvagens urbanos de Lima no Peru podem atuar como reservatório ou ser portador de agentes zoonóticos entéricos potencialmente patogênicos.

\section{ACKNOWLEDGEMENTS}

The authors would like to thank BSc. Maribel Riveros (Laboratorio de Enfermedades Entéricas, Instituto de Medicina Tropical "Alexander von Humboldt”, Universidad Peruana Cayetano Heredia) for providing a reference strain of Campylobacter jejuni, and Dr. Lorena Mori (Laboratorio de Microbiología, Facultad de Veterinaria y Zootecnia, Universidad Peruana Cayetano Heredia), for providing Escherichia coli serotype O157: H7 DNA.

\section{REFERENCES}

1. Abulreesh HH. Free living rock pigeon (Columba livia) as an environmental reservoir of enteric bacterial pathogens resistant to antimicrobial drugs in Saudi Arabia. Curr Res Bacteriol. 2011;4:28-33.

2. Bautista-Mollo GW, Barra-Clavijo R, Aruquipa-Castro RM, Acarapi-Villanueva GA, Aroja-Santos M, Balboa-Silva P. Pesquisa de Campylobacter spp. en heces de palomas y gallinas. Scientifica. 2009;7:26-8.

3. Bellido-Blasco J, González-Cano J, Galiano-Arlandis J, Herrero-Carot C, Tirado-Balaguer M, Arnedo-Pena A, et al. Factores de riesgo de los casos esporádicos de diarrea por Campylobacter, Salmonella y rotavirus en niños preescolares. An Pediatr (Barc). 2007;66:367-74.

4. Carranza C, León R, Falcón N, Neumann A, Kromm C. Caracterización y distribución de cepas de Escherichia coli potencialmente patógenas aisladas de pollos broiler de explotaciones avícolas en el Perú. Rev Investig Vet Perú. 2012;23:209-19.

5. Castillo M, Gómez F, Laos M, Salinas M. Campylobacter spp. en pacientes con cuadro diarreico que acudieron a hospitales de la ciudad de Ica, Perú. Marzo-mayo 1999. Rev Peru Med Exp Salud Pública. 2003;20:S6.

6. Coker A, Isokpehi RD, Thomas BN, Amisu KO, Obi CL. Human campylobacteriosis in developing countries. Emerg Infect Dis. 2002;8:237-44.

7. Doyle MP, Schoeni JL. Isolation of Escherichia coli O157:H7 from retail fresh meats and poultry. Appl Environ Microbiol. 1987;53:2394-6. 
CABALLERO, M.; RIVERA, I.; JARA, L.M.; ULLOA-STANOJLOVIC, F.M. \& SHIVA, C. - Isolation and molecular identification of potentially pathogenic Escherichia coli and Campylobacter jejuni in feral pigeons from an urban area in the city of Lima, Peru. Rev. Inst. Med. Trop. Sao Paulo, 57(5): 393-6, 2015.

8. Fattal B, Wax Y, Davies M, Shuval HI. Health risks associated with wastewater irrigation: an epidemiological study. Am J Public Health. 1986;76:977-9.

9. Ferens WA, Hovde CJ. Escherichia coli O157:H7: animal reservoir and sources of human infection. Foodborne Pathog Dis. 2011;8:465-87.

10. Fernández H, Gesche W, Montefusco A, Schlatter R. Wild birds as reservoir of thermophilic enteropathogenic Campylobacter species in southern Chile. Mem Inst Oswaldo Cruz. 1996;91:699-700.

11. Fernández H. Campylobacter y campylobacteriosis: una mirada desde America del Sur. Rev Peru Med Exp Salud Publica. 2011;28:121-7.

12. Grados O, Bravo N, Black R, Butzlers J. Diarrea pediátrica por Campylobacter debida a la exposición doméstica a pollos vivos en Lima, Perú. Bol Of Sanit Panam. 1989;106:205-13.

13. Huapaya B, Huguet J, Suárez V, Torres Y, Montoya Y, Salazar E, et al. Primer aislamiento de Escherichia coli O157:H7 enterohemorrágica en el Perú. Rev Peru Med Exp Salud Publica. 2001;18:38-9.

14. Hurtado L, Rojas R. Incidencia de Campylobacter sp. en pacientes de ambulatorios menores de cinco años con diarrea aguda en dos hospitales de Lima: octubre 2005-enero 2006. [tesis de Químico Farmacéutico]. Lima: Facultad de Farmacia y Bioquímica, Universidad Nacional Mayor De San Marcos; 2008.

15. Jeffrey JS, Atwill ER, Hunter A. Prevalence of Campylobacter and Salmonella at a squab (young pigeon) processing plant. Poult Sci. 2001;80:151-5.

16. Kobayashi H, Pohjanvirta T, Pelkonen S. Prevalence and characteristics of intimin- and Shiga toxin-producing Escherichia coli from gulls, pigeons and broilers in Finland. J Vet Med Sci. 2002;64:1071-3.

17. Leimbach A, Hacker J, Dobrindt U. E. coli as an all-rounder: the thin line between commensalism and pathogenicity. Curr Top Microbiol Immunol. 2013;358:3-32.

18. Lenz J, Joffe D, Kauffman M, Zhang Y, LeJeune J. Perceptions, practices, and consequences associated with foodborne pathogens and the feeding of raw meat to dogs. Can Vet J. 2009;50:637-43.

19. Lillehaug A, Monceyron-Jonassen C, Bergsjø B, Hofshagen M, Tharaldsen J, Nesse LL, et al. Screening of feral pigeon (Colomba livia), Mallard (Anas platyrhynchos) and Graylag Goose (Anser anser) populations for Campylobacter spp., Salmonella spp., avian influenza virus and avian paramyxovirus. Acta Vet Scand. 2005;46:193-202.

20. NG L-K, Kingombe CI, Yan W, Taylor DE, Hiratsuka K, Malik N, et al. Specific detection and confirmation of Campylobacter jejuni by DNA hybridization and PCR. Appl Environ Microbiol. 1997;63:4558-63.

21. Ochoa T, Contreras C, Mosquito S. Alcances sobre la situación epidemiológica de las $E$. coli diarreogénicas aisladas de niños peruanos. Can Pediatr. 2010;34:133-8.
22. Patiño L. Estudio comparativo entre la microscopía convencional y el método de cultivo con microfiltros para la identificación del Campylobacter sp. en muestras fecales de pacientes del HNGAI durante el $2^{\circ}$ semestre del 2002. [Tesis Especialidad en Patología Clínica]. Lima: Facultad de Medicina, Universidad Nacional Mayor de San Marcos; 2002.

23. Paton AW, Paton JC. Detection and characterization of Shiga toxigenic Escherichia coli by using multiplex PCR assays for stx 1 , st $x 2$, eaeA, enterohemorrhagic E. coli hlyA, $r f b O 111$, and $r f b O 157$. J Clin Microbiol. 1998;36:598-602.

24. Pedersen K, Clark L, Andelt WF, Salman MD. Prevalence of Shiga toxin-producing Escherichia coli and Salmonella entérica in rock pigeons captured in Fort Collins, Colorado. J Wildl Dis. 2006;42:46-55

25. Perales M, Camiña M, Quiñones C. Infección por Campylobacter y Shigella como causa de diarrea aguda acuosa en niños menores de dos años en el distrito de La Victoria, Lima-Perú. Rev Peru Med Exp Salud Publica. 2002;19:186-92.

26. Rivera FP, Sotelo E, Morales I, Menacho F, Medina AM, Evaristo R, et al. Shor communication: detection of Shiga toxin-producing Escherichia coli (STEC) in healthy cattle and pigs in Lima, Perú. J Dairy Sci. 2012;95:1166-9.

27. Sacristán C, Esperón F, Herrera-León S, Iglesias I, Neves E, Nogal V, et al. Virulence genes, antibiotic resistance and integrons in Escherichia coli strains isolated from synanthropic birds from Spain. Avian Pathol. 2014;43:172-5.

28. Santaniello A, Gargiulo A, Borrelli L, Dipineto L, Cuomo A, Sensale M, et al. Survey of Shiga toxin-producing Escherichia coli O157:H7 in urban pigeons (Columba livia) in the city of Napoli, Italy. Ital J Anim Sci. 2007;6:313-6.

29. Silva V, Nicoli JR, Nascimento TC, Diniz CG. Diarrheagenic Escherichia coli strains recovered from urban pigeons (Columba livia) in Brazil and their antimicrobial susceptibility patterns. Curr Microbiol. 2009;59:302-8.

30. Teske L, Ryll M, Rubbenstroth D, Hänel I, Hartmann M, Kreienbrock L, et al. Epidemiological investigations on the possible risk of distribution of zoonotic bacteria through apparently healthy homing pigeons. Avian Pathol. 2013;42:397-407.

31. Tresierra-Ayala A, Bendayan M, Bernuy A, Pereyra G, Espinoza F. Campylobacters termotolerantes en aves de corral de la ciudad de Iquitos. Folia Amazon. 1995; 7:18794.

32. Vázquez B, Esperón F, Neves E, López J, Ballesteros C, Muñoz MJ. Screening for several potential pathogens in feral pigeons (Columba livia) in Madrid. Acta Vet Scand. 2010;52:45

33. Wasteson Y. Zoonotic Escherichia coli. Acta Vet Scand Suppl. 2001;95:79-84

34. Winn W, Allen S, Janda W, Koneman E, Procop G, Schreckenberg P, et al. Koneman diagnóstico microbiológico, texto y atlas en color. $6^{\text {ta }}$ ed. Buenos Aires: Médica Panamericana; 2008.

Received: 15 October 2014

Accepted: 7 January 2015 